Technological trade

\section{Congress cool on new restrictions}

\section{Washington}

PRESIDENT Reagan asked Congress last week for stronger powers to staunch what the Administration has described as a haemorrhage of American scientific and technological secrets to the Soviet Union. But the proposals, contained in new legislation drafted by the Department of Commerce to replace the expiring Export Administration Act, were given an unsympathetic reception on Capitol Hill.

The present act authorizes the government to control the flow of exports for political or national security reasons and was used last summer to enforce the president's embargo on machinery destined for the Soviet-European natural gas pipeline. It has also been used to prevent scientists from publishing or "exporting" sensitive research, most notoriously in 1980 when commerce officials made the American Vacuum Society exclude Soviet and East European experts invited to a symposium on magnetic bubble devices.

Exporters had hoped that expiration of the act next September would be used as an opportunity to relax some controls and

restore the sanctity of international contracts. Instead, Mr Lionel Olmer, under secretary for international trade administration, told a House of Representatives foreign affairs subcommittee that the administration would not allow the needs of exporters to overshadow the "high priority" of keeping sensitive Western technology out of the hands of the Soviet Union.

The new bill would change the language of the act to emphasize the overriding importance of national security, and proposes new statutory crimes for attempting to violate the export regulations. But the most significant change is a new emphasis on efforts to stop third countries passing Western technology to the Soviet Union.

One measure proposed in the bill, to strengthen the operations of COCOM, the Coordinating Committee of NATO nations (minus Iceland and plus Japan) responsible for regulating the transfer of technology to the Eastern bloc, has wide support in Congress. There is, however, strong opposition to a provision enabling the President to stop foreign companies

\section{Professional chemists beat inflation}

ON average, British professional chemists will earn 8 per cent more in 1983 than in 1982 against an inflation rate of 5 per cent. This compares with the previous rise of 10 per cent between 1981 and 1982. The figures are taken from a survey carried out by the British Royal Society of Chemistry on their professional members, and refer to fellows and members of the society. These may be taken to represent professional graduate chemists and biochemists with more than three years working experience. The licentiate members of the society earn, on average, 75 per cent of the members' and fellows' income, although the differential is around 10 per cent for the $25-34$ year old bracket and increases to almost 40 per cent by 60-64 years. Source: The Remumeration Survey 1983, The Royal Society of Chemistry, $£ 35$.
Class of employment

Central government

UKAEA and associated Companies

Nationalized industry or public corporation

Local authority

University

Industry or commerce

Any other employer

Self-employed
25-29 $30-34 \quad 35-39 \quad 40-44 \quad 45-49 \quad 50-54 \quad 55-59 \quad 60-64$ penden $\begin{array}{lllllllll}7 & 35-39 & \mathbf{4 0 - 4 4} & \mathbf{4 5}-49 & \mathbf{5 0}-54 & \mathbf{5 5}-59 & \mathbf{6 0}-64 & \text { of age }\end{array}$

LQ $\quad 7,400 \quad 9,130 \quad 10,920 \quad 11,650 \quad 14,290 \quad 14,280 \quad 14,290 \quad-\quad 10,970$

$\begin{array}{lllllllllll}\text { Med. } & 8,000 & 10,020 & 11,700 & 14,300 & 14,990 & 16,400 & 17,000 & 17,550 & 14,290\end{array}$

$\begin{array}{llllllllll}\text { UQ } & 9,370 & 11,200 & 13,210 & 16,010 & 18,500 & 19,930 & 19,730 & - & 17,080\end{array}$

LQ - $9,81011,750-13,000-11,440$

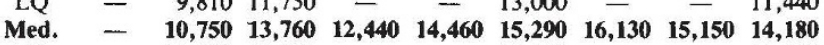

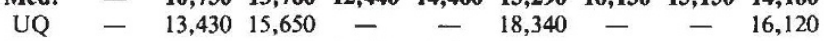
LQ $\quad-\quad 9,470 \quad 10,50012,62013,37015,17013,370-11,000$ $\begin{array}{lllllllll}\text { Med. } \quad 9,390 & 11,000 & 12,880 & 14,200 & 15,950 & 17,300 & 18,190 & 17,810 & 13,910\end{array}$ $\begin{array}{lllllllllll}\text { UQ } & - & 13,000 & 14,700 & 17,000 & 17,690 & 20,240 & 21,290 & - & 17,350\end{array}$

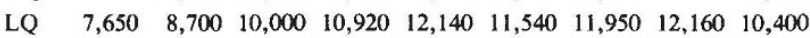
$\begin{array}{llllllllll}\text { Med. } & 8,590 & 9,790 & 11,500 & 12,810 & 13,300 & 13,790 & 13,820 & 14,760 & 12,560\end{array}$ $\begin{array}{llllllllll}\text { UQ } & 9,400 & 11,020 & 12,810 & 14,110 & 15,490 & 15,730 & 16,000 & 18,870 & 14,680\end{array}$

$\begin{array}{llllllllll}\text { LQ } & 7,470 & 8,500 & 11,550 & 13,500 & 14,940 & 15,970 & 16,180 & 16,180 & 13,500\end{array}$ $\begin{array}{llllllllll}\text { Med. } & 8,080 & 9,950 & 13,000 & 14,650 & 16,430 & 16,500 & 17,820 & 18,080 & 16,180\end{array}$ $\begin{array}{llllllllll}\text { UQ } & 8,730 & 11,500 & 14,150 & 17,100 & 17,740 & 18,500 & 21,500 & 23,000 & 17,830\end{array}$ $\begin{array}{llllllllll}\text { LQ } & 8,000 & 9,280 & 10,700 & 11,700 & 13,000 & 13,250 & 13,700 & 13,040 & 10,600\end{array}$ $\begin{array}{llllllllll}\text { Med. } \quad 9,070 & 10,870 & 12,670 & 14,500 & 16,490 & 17,500 & 17,830 & 16,510 & 13,600\end{array}$

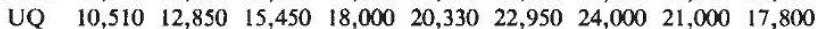

LQ - $\quad 8,340 \quad 9,80010,21011,24010,17011,750 \quad-\quad 9,860$ Med. $\quad 8,230 \quad 9,47011,60013,26013,31014,76015,900 \quad-\quad 12,800$ UQ - $10,48013,10018,08017,85019,81021,500-15,500$ LQ - - $\quad-\quad-\quad 13,500 \quad 9,000 \quad 12,000 \quad 8,000 \quad 10,000 \quad 11,000$ Med. $\quad-\quad 25,500 \quad 13,250 \quad 17,090 \quad 18,680 \quad 16,800 \quad 15,000 \quad 13,500 \quad 15,000$ UQ - - - $\quad 41,340 \quad 29,000 \quad 23,650 \quad 26,000 \quad 22,000 \quad 25,000$

LQ, Lower quartile average; Med., median; HQ, higher quartile aver age. believed to have violated the act's national security regulations from importing their goods to the United States.

It was precisely this measure that caused disarray in the Western alliance last summer during the pipeline controversy, and its appearance in the draft legislation is expected to attract international criticism at the forthcoming economic summit at Williamsburg, Virginia. Representative Donald Bonker, the Washington state Republican who chairs the foreign affairs economic policy and trade panel, warned Mr Olmer last week that a zealous pursuit of foreign trade sanctions was likely to weaken rather than strengthen cooperation between the COCOM nations.

The bill does contain some concessions designed to pacify exporters. Existing contracts could be honoured within 270 days of the imposition of any new trade sanction imposed by the president. The Department of Defense has been asked to decontrol the export of scientific equipment containing microprocessors, which at present require a validated licence irrespective of their strategic significance.

The Administration may be forced to make further concessions. Representative Bonker described the draft bill as "a sad day for American exporters" and said it was unacceptable in its present form. $\mathrm{He}$ wants to close a loophole that would let the president override the 270 day contractual grace period without declaring war or national emergency. At least seven alternative bills have been generated.

There is no sign of parallel concessions on the horizon for the scientific community, however. A report on scientific communication and national security published last October by the National Academy of Sciences (NAS) called for amendments in the existing act to exempt domestically available unclassified information and information not directly related to national security from the formal licensing procedure. These proposals have not been incorporated in the draft bill.

The omission may be simply a case of crossed bureaucratic wires. The NAS report was turned over to the White House Office of Science and Technology Policy (OSTP) last year and a response was expected last month. But the OSTP review was in turn subsumed in a larger and as yet unfinished inter-agency review of technological export being conducted by the National Security Council. An OSTP spokesman was unable to say whether the office had advised the Commerce Department on the contents of the draft bill.

If there is a less benign reason for the omission, however, the academy may find it difficult to make a late entry into a debate which has been dominated by the impact of the act on exporters rather than scientists. An NAS spokesman said last week: "We are concerned about it still and intend to see that the views of the NAS panel are taken into account in the debate on the Hill"'. 